\title{
The Determinants of Office Rents and Yields: The International Evidence ${ }^{\dagger}$
}

\author{
Jedrzej Bialkowski \\ UC Business School \\ University of Canterbury
}

\author{
Sheridan Titman \\ McCombs School of Business \\ University of Texas at Austin
}

\author{
Garry Twite \\ Faculty of Business and Economics \\ University of Melbourne
}

May 26, 2018

\begin{abstract}
Monocentric urban models predict that office rents will be higher in larger and more prosperous cities with better transport and stronger agglomeration benefits. In addition, rental yields should be lower in growing cities when the supply of new office space is more constrained and the supply of capital is less constrained. We present evidence that is generally consistent with these theories.
\end{abstract}

Keywords: Global real estate market, Capitalization rate, Office rental yield, Office rental rates, Financial centres, Public Transport

JEL codes: D4, G29, R1, R4, R33

\footnotetext{
$\dagger$ We are grateful to Paul Lunn and Raymond Torto for providing us with access to the CBRE ERIX global real estate database.

${ }^{\ddagger}$ Corresponding author. Faculty of Business and Economics, University of Melbourne, Melbourne VIC 3010, Australia. Email: garry.twite@unimelb.edu.au; phone: +61 3 8344-7786; fax: +61 383441900.
} 


\section{Introduction}

The determinants of rental rates are well understood in the urban economics literature. For example, the canonical monocentric city models of Alonso (1964), Mills (1967) and Muth (1969) predict that central business district (CBD) rents will be higher in bigger and more prosperous cities. More recent theory stresses the importance of agglomeration externalities, which makes firms more efficient when they locate in close proximity to each other (Lucas and Rossi-Hansberg (2002)). These theories suggest that CBD rents will be higher when it houses an industrial cluster with strong agglomeration externalities that require face to face interactions. ${ }^{1}$ These advantages of agglomeration, and the resulting CBD rents, are higher still in cities with transit systems that more efficiently transport workers from outlying areas to the CBD.

The urban economics literature devotes less attention to the rental yields of commercial real estate. The rental yield, the rental rate divided by the property's value, is a function of the expected growth rate of future rents along with the rate at which those future rents are discounted. As such, rental yields are expected to be lower in growing cities that are likely to have future supply constraints and are expected to be higher in places with higher discount rates and capital constraints.

To explore these ideas, we analyze data on the rental rates and the rental yields of prime office buildings in 52 of the largest cities in 29 developed and developing countries over the period 2000-2017. The data set, provided by CBRE, is standardized in the sense that it is based on the rents and values of a hypothetical high rise Class A office property in different CBDs around the world. The rental yield, as measured by $\mathrm{CBRE}$, is the current rental rate divided by the value of a hypothetical high rise Class A office building that is fully rented at the prevailing rental rates. ${ }^{2}$ In

\footnotetext{
${ }^{1}$ See Duranton and Puga (2014) for a review of both the recent theoretical and empirical literature.

${ }^{2}$ Previous studies make use of appraisal-based capitalization rates within a single country context. For example, Sivitanides, Southard, Torto and Wheaton (2001) make use of the NCREIF capitalization rates.
} 
addition to our broader sample, we do a separate analysis of a sub-sample of European cities, which provides a sample that is more homogenous on some dimensions, perhaps, allowing a clearer analysis of the dimensions in which they differ. While our main focus is on office space in central business districts (CBDs), we also consider a sample that includes suburban office rental rates and rental yields. This enables us to make use of the difference between $\mathrm{CBD}$ and suburban rental rates and rental yields to better understand the influence of agglomeration and transportation.

We examine rental rates and rental yields as functions of variables that capture various aspects of the size, economic activity, and transit infrastructure of the cities in our sample. To capture agglomeration benefits, we consider whether the cities are financial and government centers. Our conjecture is that all else equal, face to face interaction is more important in financial and government centers, making CBD locations in these cities more valuable relative to both suburban prime office space in the same city and prime office space in cities that are not financial or government centers.

The analysis also examines how characteristics of the debt markets influence rental rates and rental yields. Specifically, our regressions include the real interest rate, inflation rate, and the countries' credit ratings as independent variables. Our conjecture is that higher capital costs should increase rental yields, and if higher financing costs limit supply, it should increase rental rates. In theory, inflation can have either a positive or negative effect on property prices. Inflation increases nominal borrowing rates, which tends to increase the risk of borrowing, making it more difficult to raise money to develop and increase the supply of office buildings. However, because real estate tends to be an inflation hedge, office buildings can potentially be more attractive, and require lower real rates of return, when the inflation rate is higher. 
Our cross-city analysis of rents is consistent with the predictions of the monocentric city models. CBD rents tend to be higher in larger and more prosperous cities and we observe higher rents in cities with more rail infrastructure. After controlling for both population and per capita income, rents are significantly higher in financial centers. However, we do not observe higher rents in government centers. We find that rents tend to be higher in countries where debt is more expensive. In addition to the effect of real interest rates, inflation increases rental rates, which is consistent with property owners requiring higher risk premiums in countries with higher inflation.

Our analysis of rental yields is generally consistent with the idea that future supply constraints reduce rental yields. Our conjecture is that the supply of new office buildings is likely to be more constrained in CBDs with better rail infrastructure because there is limited access to transit stops. Intuitively, rental yields should be lower in supply constrained CBDs; these locations are likely to experience greater future rental increases since future increases in demand tend to be offset less by increased supply. We find that rental yields are indeed lower in denser cities with better transport infrastructure. We also find that rental yields are lower in growing cities and are higher in locations with higher real interest rates. We also find higher rental yields in locations with higher risk and rates of inflation, suggesting the risks associated with higher nominal borrowing costs more than offsets any advantage associated with holding an asset that is a good inflation hedge.

Although the sample is relatively small, our analysis of the difference between CBD and suburban rental rates and rental yields is also interesting. We conjecture that being located in the $\mathrm{CBD}$ relative to an outlying location is relatively more valuable in financial and government centers, where face to face contact is more important. In addition, the relative benefit of being in the $\mathrm{CBD}$ is higher if there is rail transport to the $\mathrm{CBD}$, and if the suburban locations are relatively 
far away. Consistent with the importance of proximity in financial centers we find that the difference between CBD and suburban rents is especially high and yield differences are lower in financial centers, but we again find no evidence of higher rents in the CBDs of government centers.

Although we are not the first to consider these issues, most existing studies focus on the determinants of both rental and cap rates within individual cities ${ }^{3}$ or countries. ${ }^{4}$ In addition to using a more standardized data set, relative to existing studies, we consider both a larger number of countries, developed and developing, and a broader set of city and country characteristics that are likely to influence property prices. We believe that we are the first to make use of the considerable variation in rental rates and rental yields across countries and between cities, together with the cross-sectional variation in the size, economic activity, transit infrastructure and the economic mix of the cities. We also believe that we are the first to consider differences between suburban and CBD rents in a cross-country study. ${ }^{5}$

The paper is organized as follows. Section 2 describes the methodology we use to examine the influence of agglomeration, public transport efficiency and job density on both rental rates and rental yields. The data we use and our sample are described in Section 3. Section 4 presents our results, and Section 5 draws some conclusions.

\footnotetext{
${ }^{3}$ Examples of individual city empirical studies include Mills (1992) (Chicago), Sivitanidou (1995) (Los Angeles), Englund, Gunnelin, Hoesli and Soderberg (2004) (Stockholm), Oven and Pekdemir (2006) (Istanbul), Kim (2007) (Seoul), and Ke and White (2009) (Shanghai).

${ }^{4}$ Examples of multiple cities analysis within the U.S. - include Sivitanidou and Sivitanides (1999), MourouziSivitandou (2002), Plazzi, Torous and Valkonov (2008), Brounen and Jennen (2009a), McDonald and Dermisi (2009), and Chervachidze and Wheaton (2011).

${ }^{5}$ There does exist a small literature that examines the cross-sectional variation in the determinants of both rental and cap rates across countries (Giussani, Hsia and Tsolacos (1993) (Western Europe), Wit and Dijk (2003) (Europe, Asia and U.S.), and Brounen and Jennen (2009b) (Western Europe)). These studies include fewer cities and consider fewer explanatory variables.
} 


\section{Methodology}

Our proposed tests explore the relation between rental rates and yields; agglomeration (both finance industry and government clustering), job density and transport efficiency (both usage and time travelled), controlling for city and country characteristics, where appropriate. City level controls include CBD population, CBD population growth and CBD economic activity (GDP per capita). While country level controls include real interest rates, inflation and the country's sovereign credit rating as a measure of political risk. Our baseline regression is:

$$
\begin{aligned}
& Y_{i, t}=\beta_{1}^{\prime} \text { Agglomeration }_{i, t-1}+\beta_{2}^{\prime} \text { Job density }_{i, t-1}+\beta_{3}^{\prime} \text { Transport }_{i, t-1} \\
+ & \beta_{1}^{\prime} \text { City characteristics }_{i, t-1}+\beta_{2}^{\prime} \text { Country characteristics }_{c, t-1}+\delta_{t}+\varepsilon_{i t}
\end{aligned}
$$

where $i$ indexes cities, $c$ indexes countries, and $t$ indexes time in years. The four dependent variables $(Y)$ we examine include $\mathrm{CBD}$ rental rates, $\mathrm{CBD}$ rental yields and the difference between $\mathrm{CBD}$ and suburban rental rates and rental yields. The vector $\delta_{t}$ represents year indicators that are included to account for aggregate fixed effects. We lag country and city level variables one year. Standard errors are clustered by city/suburb and time.

We estimate rental rate and yield regressions for the full sample of 52 cities from 29 countries over the period $2000-2017$. We also estimate separate regressions that include only the 32 European cities in our sample. We partition the sample by time period, 2000-2008 and 20092017. This partitioning enables us to make use of the decline in commercial property values and subsequent reversal around the Great Recession, to capture any time series variation in the importance of agglomeration, job density and transport efficiency in determining rental rates and yields. 
Finally, we estimate the difference in rental rates between CBD and suburban Class A office space for a sample of 86 suburbs across 19 cities (13 countries) and rental yields for 36 suburbs across 10 European cities ( 9 countries). This enables us to focus on a second aspect of the efficiency of a city's transport infrastructure beyond usage, namely the time taken to travel between CBD and suburban area by either public or private transport.

\section{Data and Sample}

Our primary data source for both city and suburb level data is the CBRE ERIX database, which for the period 2000-2017 provides us with annual rental rates and rental yields for prime office space, both CBD and suburban. Rent is the natural logarithm of US dollar rent per square metre for Class A office space of standard size for a blue chip occupier. The rental rates in this database represent CBRE's market view, which is based on an analysis/review of actual transactions and reflect relevant transactions that were completed in the market at the time but need not be exactly identical to any of them. ${ }^{6}$

The prime rental yield, Yield, is defined as the ratio of the annual net rental income (rent minus non-recoverable costs) and the total amount invested (purchase price plus purchasers' oncosts), achievable for a high rise Class A office building of standard size. It is based both on sale and purchase contracts concluded during the survey period, but again, need not be exactly identical to any of them. If there are no relevant transactions during the survey period, it will be based on expert opinion of market conditions, using the same criteria on building size and specification.

The proportional difference in prime rental rates between a city's CBD and its suburbs, CBD-Suburb rent, is defined as the US dollar prime rent per square meter for CBD Class A office

\footnotetext{
${ }^{6}$ CBRE Global Research and Consulting. March 2014. "ERIX Methodology: Variable Definitions"
} 
space minus the US dollar prime rent per square meter for suburban Class A office space divided by the US dollar prime rent per square meter for CBD Class A office space, expressed as a fraction. While the proportional difference in prime rental yields between a city's CBD and its suburbs, CBD-Suburb yield, is defined as the prime yield for CBD Class A office space minus the prime yield for suburban Class A office space divided by the prime yield for CBD Class A office space.

Table 1 provides a description of our sample, which includes 52 cities across 29 countries, including Europe (both Western and Eastern Europe), Asia/Pacific and North America. We note, however, that coverage of the sample cities varies across countries; we have multiple cities in 11, mostly European, countries. In addition to the full sample, we also analyze as a separate sub-sample, 32 European cities across 20 countries, including both Western and Eastern European cities. We next consider a sub-sample which includes prime rental rates for 86 suburbs across 19 mostly European cities. The cities outside of Europe represented in the suburban rental rate sub-sample are Beijing (2 suburbs), Shanghai (1 suburb), Seoul (2 suburbs); Chicago (1 suburb), Los Angeles (3 suburbs), and New York (3 suburbs). Further, the coverage of the sample of suburbs varies across cities, with German cities/suburbs accounting for $43 \%$ of the suburbs. Finally, we consider a subsample which includes prime rental yields for 36 suburbs across 10 European cities, with the omission of German cities/suburbs (Berlin, Frankfurt and Munich) from this sub-sample.

(Table 1 about here)

To gain a basic idea about how rental rates and yields differ across countries, we compute the mean US dollar rental rate and rental yield by country for the period from 2000 to 2017. As can be seen in Figure 1, European countries occupy both ends of the rental rate spectrum. Three of 
the 5 highest rental rates are in countries that include financial centers, Hong Kong, Switzerland and UK and in the case of Hong Kong and UK both have extensive transport infrastructure, while the lowest 5 are observed in countries that include capital cities, Denmark, Hungary, New Zealand, Portugal and Thailand.

\section{(Figure 1 about here)}

To gain an understanding of how prime office rental rates have changed through time, and in particular around the Great Recession, we also compute the mean US dollar rental rate each year for the period from 2000 to 2017. We also show the mean US dollar rental rate for all European countries.

(Figure 2 about here)

Figure 2 reveals a consistent pattern over time for both the full sample and the sample of European cities. We observe that for the full sample and the sample of European cities, US dollar rental rates rose over the period from 2000-2007, declining in the 2007-2008 period of the Great Recession, recovering in 2009, declining again in 2013 and recovering in 2016. This pattern can be attributed in part to relative movements in USD exchange rates. To illustrate this, we plot in Figure 2 both the US dollar and Euro denominated rental rates for those European countries that have adopted the Euro. As we show, rents in Euros did increase over this sample period.

(Figure 3 about here) 
Figure 3 presents the mean rental yield by country and mirrors Figure 1. As in Figure 1, European countries occupy both ends of the rental yield spectrum.

Our explanatory variables include measures of agglomeration, job density and transport efficiency. Transport is the natural logarithm of the number of public transport boardings per capita, as reported by the International Association of Public Transport (UITP), which is part of the Mobility in Cities Database and based on 1995, 2002 and 2015 surveys. In addition, from the same source, Job density is the natural logarithm of the number of jobs per hectare.

The variable Financial center is a dummy variable, which is equal to one, for cities which are ranked in the top 10 in the biannual ranking Global Financial Centres Index (GFCI) prepared by the $\mathrm{Z} /$ Yen Group. One hundred and six financial centers were actively researched and eighty eight financial centers appeared in GFCI 21 (March 2017). The GFCI ranking is prepared using one hundred and one factors over five broad groupings - business environment, financial sector development, infrastructure, human capital and reputation. Capital city is a dummy variable equal to one for cities which are the capital city of one of the 29 countries in our sample and zero otherwise.

For the CBD of each city, we collect information on the population from Skyscrapers.com - Emporis GmbH. The size of the city is measured as the natural logarithm of its population, Population. Population growth represents the annual growth rate of the population of the CBD in each city. We also collected metropolitan GDP per capita in USD from the Mobility in Cities Database. The prosperity of the CBD of each city is measured as the natural logarithm of metropolitan GDP per capita in USD, GDP per capita. We include Short real interest measured as 3 month nominal interest rate minus the inflation rate, where Inflation is measured as the change in 
country CPI index. Both the 3 month nominal interest rate and the change in the CPI are sourced from the World Bank Development Indicators. We include sovereign debt rating as a proxy for political risk. Rating is the natural logarithm of a numerical score between 1 and 18 , which represents the Fitch country rating. The highest rating of AAA corresponds to 1 and lowest rating of $\mathrm{D}$ corresponds to $18 .^{7}$

For each suburb of each city, we collect information on the road distance and travel times between a suburb and its $\mathrm{CBD}$, taken from Google Maps. Distance is measured as the natural logarithm of the road distance between a suburb and its CBD in kilometers. Travel time - public is measured as the natural logarithm of the travel time by public transit from a suburb to its CBD at 8:30AM on a working day (Wednesday) in hours. Travel time - car is measured as the natural logarithm of the travel time by car from a suburb to its CBD at 8:30AM on a working day (Wednesday) in hours.

\subsection{Summary statistics}

Table 2 presents summary statistics for both the full sample, comprising 52 CBDs across 29 countries, the European sub-sample of 32 CBDs across 20 countries, and the sample of 86 suburban prime office locations across 19 cities.

For the full sample, prime rental rates are on average US\$524.23 per square meter for Class A CBD office space and prime rental yields average $6.07 \%$. On average there are 295.58 trips per capita per year on public transport and 32.48 jobs per hectare in the CBD. Almost $22 \%$ of the cities where ranked as a top 10 financial centers in at least one year during the sample period, and $44 \%$ are capital cities. In financial centers rental rates tend to be higher - on average US\$946.90 per

\footnotetext{
${ }^{7}$ Chervachidze and Wheaton (2011) also include a measure of debt availability, which we do not include due to data limitations in some of the countries included in our study.
} 
square meter for Class A CBD office space, and rental yields tend to be lower - on average 5.21\%. In contrast, CBD rents in capital cities are slightly lower - on average US\$508.31 per square meter, and rental yields are slightly higher - on average $6.19 \%$.

For the sample of European cities, rental rates are on average US\$493.28 per square meter for Class A CBD office space and rental yields average 5.70\%. While both public transport usage and job density is higher in Europe - 356.2 trips per capita per year on public transport and 28.23 jobs per hectare in the CBD. We classify only $16 \%$ of European cities as top 10 financial centers in at least one year and 56\% are capital cities. Rental rates in European financial centers are quite high when compared to the full sample, on average US\$956.44 per square meter, and rental yields average $4.56 \%$. Rental rates tend to be lower for capital cities, on average US\$524.55 per square meter, and rental yields average 5.94\%.

Class A suburban rental rates (yields) are on average $40.19 \%$ lower (22.17\% higher) than Class A rental rates in the city's CBD. The lower rents in the suburbs probably reflect reduced agglomeration benefits relative to the $\mathrm{CBD}$ and the higher rental yields probably reflect the fact that suburban locations tend to be less constrained. While the distance between suburban prime office space and the CBD is 12.03 kilometers and the time taken to travel this distance by public transport versus private car is quite similar, 31.47 versus 30.65 minutes.

(Table 2 about here)

Table 3 presents correlations between rental rates, rental growth rates, rental yields, financial centers, capital cities, transport and job density, together with city level and country level controls for the both the full sample and the sub-sample of European cities. These univariate correlations 
indicate that rental rates are higher in larger, more prosperous cities with a higher frequency of public transport usage and more jobs. The univariate correlations also indicate that $\mathrm{CBD}$ rental rates are higher in financial centers, but not in governmental centers and that rental rates are higher when inflation is higher and when interest rates and political risk are lower. The correlations also indicate that rental yields are lower in cities that are more prosperous, where public transport usage is higher, where job density is higher, and where interest rates, inflation and political risk are higher. Finally, rental yields tend to be lower in financial centers but higher in capital cities.

In addition, Table 3 presents correlation between the proportionate difference in rental rates and yields between CBD and suburbs, travel distances and travel times. These univariate correlations indicate that differences in rental rates (yields) are higher (lower) in more prosperous cities with longer distances and longer travel times between the CBD and suburban Class A office space. We also find that the proportionate difference in rental rates (yields) between CBD and suburbs are higher (lower) for financial centers but lower (higher) for government centers.

(Table 3 about here)

To investigate whether these variables are likely to be subject to collinearity problems in our later regression analysis, we examine the correlations between the independent variables that are used in our analysis. From Table 3, we see that most variables are not highly correlated with each other, with some notable exceptions. In particular, the correlation between our transport measure and job density is $70.52 \%$. While in the suburban sample we observe similar correlations between our distance and travel time measure. This multi-collinearity makes it difficult to interpret the impact 
of some of the individual variables; hence we examine these variables in separate regressions to mitigate this problem.

\section{Regression Results}

In this section, we begin by presenting our analysis of the determinants of rental rates and rental yields in CBDs. We will then analyse differences between CBD and suburban office rents.

\subsection{CBD rental rates}

Table 4 presents the results of regressions of rental rates on measures of agglomeration, job density and the efficiency of the city's urban rail network, together with city and country level characteristics. We report separate regressions for our transport and job density measures to mitigate the impact of multi-collinearity. Columns (1) and (2) report the regressions for the full sample using yearly data from 2000 to 2017, columns (3) and (4) provide evidence for the 20002008 sub-period, and columns (5) and (6) provide evidence for the 2009-2017 sub-period. Columns (7) and (8) provide evidence for a subsample representing European cities.

For the full sample of 52 cities, our evidence is generally consistent with the monocentric urban models. Rents are higher in larger cities, and although the effect is not statistically significant, per capita GDP is positively related to rents. We also find that rents are significantly higher in financial centers. Indeed, all else equal, rents in financial centers are 53.3\% higher than in other cities. We find mixed results for rents in government centers, but the effect is very small and insignificant. A more efficient rail network and greater job density are also associated with higher rents. However, the impact is less significant; a one-standard deviation increase in the frequency of usage of the city's rail network (jobs in the CBD) leads to a $1.11 \%(1.10 \%)$ increase in CBD rental 
rates. Our evidence also suggests that conditions in the financial markets can affect rental rates. In particular, we find that $\mathrm{CBD}$ rental rates are higher in places with higher short-term real interest rates and inflation rates. A $1 \%$ increase in the real interest rate (inflation) leads to a $4.53 \%(6.22 \%)$ increase in $\mathrm{CBD}$ rental rates. ${ }^{8}$

There are some significant differences between the subsamples. The observation that rents are higher in CBDs with larger rail networks and greater job density only holds during the earlier sub-period. While the finding that $\mathrm{CBD}$ rental rates are higher with higher inflation only holds during the latter part of the sample, 2009 to 2017 . Our regressions also indicate that being a financial center has a greater effect on CBD rents in Europe; ceteris paribus, rents in European financial centers are $73.9 \%$ higher. We also find that rents are higher in cities with more prosperous CBDs. However, the association between transport utilization and job density is smaller and insignificant in the European subsample.

(Table 4 about here)

\subsection{CBD rental yields}

Table 5 examines the determinants of the rental yields for CBD Class A office space. The table presents the results of the regression of rental yields on measures of agglomeration, job density and the efficiency of the city's urban rail network, together with city and country level characteristics. We report separate regressions for our transport and job density measures to mitigate the impact of multi-collinearity. Columns (1) and (2) report the regressions for the full sample over the period

\footnotetext{
${ }^{8}$ These findings reinforce the prior literature on the importance of a city's wealth and GDP, real interest rates and employment in the financial services sector on rents (Brounen and Jennen (2009b), Wit and Dijk (2003), Giussani, Hsia and Tsolacos (1993), Ke and White (2009), Sivitanidou and Sivitanides (1999), Mourouzi-Sivitandou (2002), and McDonald and Dermisi (2009)).
} 
2000-2017, columns (3) and (4) provide evidence for the 2000-2008 sub-period, and columns (5) and (6) provide evidence for the 2009-2017 sub-period. Columns (7) and (8) provide evidence for a subsample representing European cities.

We do not find a significant association between agglomeration and the rental yields for CBD Class A office space. However, we find that rental yields are lower in CBDs with a more efficient rail network and greater job density. A one-standard deviation increase in the frequency of usage of the city's rail network (jobs in the CBD) leads to a 1.1 (1.0) basis point decrease in CBD rental yields.

Our results are generally consistent with future supply constraints, rental yields are lower in growing cities, as expected, rental yields are higher in locations with higher real interest rates. A $1 \%$ increase in city's population growth rate leads to a 7.85 basis point decrease in CBD rental yields.

Reflecting the impact of the cost of capital on rental yields, we find that rental yields are higher when the real interest rate, inflation and political risk are higher. A $1 \%$ increase in real interest rates (inflation) leads to a 13.9 (37.1) basis point increase in CBD rental yields. While an increase of one rank in the countries sovereign debt rating leads to a 14.1 basis point increase in CBD rental yields. ${ }^{9}$

There are few differences between the subsamples. The observation that CBD rental yields are lower in CBDs with greater job density only holds during the latter part of the sample, 2009 to 2017. In Europe, the significant difference is the finding that rental yields are lower in cities with more prosperous CBDs.

\footnotetext{
${ }^{9}$ These findings reinforce the prior literature on the importance of a city's wealth and GDP, real interest rates, inflation and risk on rental yields (Sivitanidou and Sivitanides (1999), Sivitanides, Southard, Torto and Wheaton (2001), Plazzi, Torous and Valkonov (2008), Chervachidze, Costello and Wheaton (2009), Chervachidze and Wheaton (2011a and b)).
} 
(Table 5 about here)

\subsection{CBD versus Suburban rental rates}

Table 6 examines the determinants of the difference between the rental rates of CBD Class A office space and suburban Class A office space. The table presents the results of the regression of the difference in rental rates on measures of agglomeration, job density, the efficiency of the city's urban rail network, travel distances and travel times, together with city level characteristics. We report separate regressions for our measures of distance and travel time to mitigate the impact of multi-collinearity. Likewise, as with Table 4, we report separate regressions for our transport and job density measures. Columns (1), (2) and (3) report regressions that include our transport measure, together with distance, time travelled by public transport and time travelled by private car, while columns (4), (5) and (6) report the regressions which include our job density measure, together with distance, time travelled by public transport and time travelled by private car. Panel A reports results for the full sample of 86 suburbs across 19 cities for which we have suburb-year observations of rental rates, Panel B for the sub-sample of 36 suburbs across 10 European cities with suburb-year observations of both rental rates and yields.

In Panel A we find that the prosperity of the city and travel distances (times) between the CBD and the suburbs affect the difference in rental rates between the CBD and suburbs. The difference in rents between CBD Class A office space and suburban Class A office space is larger, the longer travel times and distance between suburbs and the CBD. Likewise, the difference is larger in more prosperous and denser cities with more efficient rail networks and is also larger when the CBD is a financial center. 
The change of classification of a city's CBD to a financial center leads to a $52.6 \%$ increase in the difference between CBD Class A office space rental rates and suburban Class A office space rental rates, which is of similar magnitude to the change in CBD rental rates reported in Section 4.1. Again, the effect of increased utilization of the rail network is less significant, a one-standard deviation increase in the frequency of usage of the city's rail network leads to a $0.10 \%$ increase in the difference between CBD Class A office space rental rates and suburban Class A office space rental rates.

Finally, consistent with Sivitanidou (1995), ${ }^{10}$ we find that CBD and suburban rental rates differ more the longer the distance between the $\mathrm{CBD}$ and the suburb and the greater the travel time, both public transit and private car. For example, a one-standard deviation increase in the travel time by car from a suburb to its CBD leads to a $0.09 \%$ increase in the difference between CBD Class A office space rental rates and suburban Class A office space rental rates, which is of similar magnitude to the impact of the usage of the city's rail network on the difference between CBD and suburban Class A office space rental rates.

In Panel B we analyze a sub sample of 36 suburbs across 10 European cities, omitting German cities (Berlin, Frankfurt and Munich), with suburb-year observations of both rental rates and yields. ${ }^{11}$ We examine this sub-sample of CBD and suburban Class A office space rental rates to enable a comparison with our analysis of the determinants of the difference between CBD and suburban Class A office space rental yields in the following section. Consistent with the results for the full sample (Panel A) we find that the prosperity of the city, travel distances (times) between the $\mathrm{CBD}$ and the suburbs and whether the $\mathrm{CBD}$ is a financial center affect the difference in rental

\footnotetext{
${ }^{10}$ Sivitanidou (1995) finds that office rental rates are lower in the Los Angeles area, the greater the distance to the CBD or airport, arguing that this distance represents the cost of business trips for face-to-face meetings.

${ }^{11}$ This also has the benefit of examining the robustness of our results to the exclusion of Germany cities, which represents $43 \%$ of our original city/suburb sample.
} 
rates between the CBD and suburbs. The difference in rents between CBD Class A office space and suburban Class A office space is larger in cities with more prosperous CBDs, where the CBD is a financial center, the longer the distance between the CBD and the suburb and the greater the travel time.

However, contrary to expectations, in this sub-sample of European cities, we find that the difference in rents between CBD Class A office space and suburban Class A office space is smaller when the city's rail network is more efficient -- a one-standard deviation increase in the frequency of usage of the city's rail network leads to a $0.04 \%$ decrease in the difference between CBD Class A office space rental rates and suburban Class A office space rental rates. This result is consistent with the negative relationship between transport utilization and CBD rents reported for a subsample of European cities in Table 4.

(Table 6 about here)

\subsection{CBD versus Suburban rental yields}

Table 7 examines the determinants of the difference between CBD Class A office space rental yields and suburban Class A office space rental yields for a sub-sample of 36 suburbs across 10 European cities. The table presents the results of the regression of the difference in rental yields on measures of agglomeration, job density, the efficiency of the city's urban rail network, travel distances and travel times, together with city level characteristics. We report separate regressions for our measures of distance and travel time to mitigate the impact of multi-collinearity. Likewise, as with Table 5, we report separate regressions for our transport and job density measures. Columns (1), (2) and (3) report regressions that include our transport measure, together with distance, time 
travelled by public transport and time travelled by private car, while columns (4), (5) and (6) report the regressions which include our job density measure, together with distance, time travelled by public transport and time travelled by private car.

We find that agglomeration influences the difference in yields between CBD Class A office space and suburban Class A office space. The difference is smaller in cities where the CBD is a financial center, but larger for a government center. The change of classification of a city's CBD to a financial center (government center) leads to an $81.1 \%$ decrease $(44.7 \%$ increase) in the proportionate difference between CBD Class A office space rental yields and suburban Class A office space rental yields.

We find mixed results with respect to the influence of the efficiency of a city's transport infrastructure on the difference between $\mathrm{CBD}$ and suburban rental yields. We find that CBD job density and the efficiency of the city's rail network affect the difference in rental yields between the CBD and suburbs. The difference in yields between CBD Class A office space and suburban Class A office space is larger in cities with a more efficiency of the rail network and greater job density. A one-standard deviation increase in the frequency of usage of the city's rail network (jobs in the $\mathrm{CBD})$ leads to a $0.04 \%(0.03 \%)$ increase in in the proportionate difference between $\mathrm{CBD}$ Class A office space rental yields and suburban Class A office space rental yields. While, the difference in yields between CBD Class A office space and suburban Class A office space is lower the greater are the travel distances (times) between the CBD and the suburbs. For example, a onestandard deviation increase in the travel time by public transport from a suburb to its CBD leads to a $0.03 \%$ decrease in the proportionate difference between CBD Class A office space rental yields and suburban Class A office space rental yields. 
(Table 7 about here)

\subsection{Endogeneity Issues}

The reduced form regressions we report should be interpreted with some caution since some of the independent variables are clearly endogenous. In particular, cities are likely to expend more resources on rail transit and road networks when the agglomeration benefits of density are higher and job density will tend to be higher in cities with better transit options. The exact location of suburbs is also endogenous; suburbs may be closer to the CBD when the agglomeration benefits are higher. A structural model that accounts for these endogenous relationships is beyond the scope of this study and probably is not feasible given our limited data. However, we have estimated our regressions including only those independent variables that can plausibly be viewed as exogenous. All of our main results continue to hold.

(Table 8 about here)

\section{Conclusion}

Urban theory suggests that CBD rents should be higher in larger and more prosperous cities (i.e., more productive cities) with greater agglomeration benefits and in cities in which transportation to the $\mathrm{CBD}$ is less costly. Finance theory indicates that rental yields should be higher when rental rates are likely to grow more slowly and where the cost of capital is higher. We believe this is the first paper that examines these propositions within the context of a broad cross-section of international cities. 
For the most part, our analysis is consistent with both the urban and finance theories. In particular, $\mathrm{CBD}$ rents and the difference between $\mathrm{CBD}$ and suburban rents tend to be higher in larger and more prosperous cities, and are especially high in financial centers, where agglomeration externalities are especially strong. CBD rents also tend to be higher in cities with denser employment and better rail transit. We also find that attributes of the debt markets affect rental rates as well as rental yields. In particular, inflation increases both rental rates and rental yields, and other measures of capital costs, e.g., real interest rates and country credit ratings, have the expected effect on rental yields. We also find that rental yields are lower in high growth cities and denser cities that have better rail transit. Our explanation is that rents are more likely to grow in these more constrained cities, because increases in office demand is likely to be offset less by increased supply.

Before concluding, we should note that at this stage we are providing reduced form estimates, so one should not consider the analysis a direct test of any theory. Some of the variables that are of interest are clearly endogenous, e.g., cities are likely to expend more resources on rail transit when the agglomeration benefits of density are higher, and of course, job density will tend to be higher in cities with better transit options. Although our main results continue to hold in regressions that include only variables that can be viewed as exogenous, future work should attempt to sort through these endogeneity issues. These issues, however, are likely to be challenging, given our limited data. Hopefully, one can potentially sort through these issues with a larger cross-section of cities and plausible exogenous instruments that capture cross-sectional differences in agglomeration benefits. 


\section{References}

Brounen, D., and Jennen, M. 2009a. Asymmetric Properties of Office Rent Adjustment. Journal of Real Estate Finance and Economics, 39, 336-358.

Brounen, D., and Jennen, M. 2009b. Local Office Rent Dynamics a Tale of Ten Cities. Journal of Real Estate Finance and Economics, 39, 385-402.

Cervero, R.B., and Duncan, M. 2002. Transit's Value-Added Effects: Light and Commuter Rail Services and Commercial Land Values. Journal of the Transportation Research Board. 1805, 8-15.

Chervachidze, S. J., Costello, D., and Wheaton, W. 2009. The Secular and Cyclic Determinants of Capitalization Rates: The Role of Property Fundamentals, Macroeconomic Factors, and Structural Changes. The Journal of Portfolio Management. 35, 50-69.

Chervachidze, S., and Wheaton, W. 2011 a. What Determined the Great Cap Rate Compression of 2000-2007, and the Dramatic Reversal During the 2008-2009 Financial Crisis? Journal of Real Estate Finance and Economics, 46, 208-231.

Chervachidze, S., and Wheaton, W. 2011b. The Cross-Sectional Dispersion of Commercial Real Estate Returns and Rent Growth: Time Variation and Economic Fluctuations. Real Estate Economics. 36, 403-439.

Duranton, G. and Puga, D. 2014. The Growth of Cities. Handbook of Economic Growth, ed 1, vol 2, Ch 5, 781-853.

Englund, P., Gunnelin, A., Hoesli, M. and Soderberg, B. 2004. Implicit Forward Rents as Predictors of Future Rents. Real Estate Economics 32(2):183-215.

Glaeser, E., and Ponzetto, G. 2010. Agglomeration Economics, University of Chicago Press.

Giussani, B., Hsia, M., and Tsolacos, S. 1993. A Comparative Analysis of the Major Determinants of Office Rental Values in Europe. Journal of Property Valuation and Investment, 11(2), 157173.

Jennen, M., and Brounen, D., 2009. The Effect of Clustering on Office Rents: Evidence from the Amsterdam Market. Real Estate Economics 37(2): 185-208.

Ke, Q., and White, M. 2009. An Econometric analysis of Shanghai office Rents. Journal of Property Investment and Finance, 27(2), 120-139.

Kim, J. 2007. Discriminant Impact of Transit Station Location on Office Rent and Land Value in 
Seoul: An application of spatial econometrics. Journal of Transport Economics and Policy, 41(2), 219-245.

Lucas, R.E., and Rossi-Hansberg, E. 2002. On the Internal Structure of Cities, Econometrica. 70, 1445-1476.

McDonald, J. F., and Dermisi, S. 2009. Office Building Capitalization Rates: The Case of Downtown Chicago, Journal of Real Estate Finance and Economics. 39, 472-485.

Mills, E. S. 1967. An Aggregative Model of Resource Allocation in a Metropolitan Area. American Economic Review. 57, 197-210.

Mills, E. S. 1992. Office Rent Determinants in the Chicago Area. Real Estate Economics. 20, 273-287.

Mourouzi-Sivitanidou, R. 2002. Office Rent Processes: The Case of U.S. Metropolitan Markets. Real Estate Economics. 30, 317-344.

Muth, R. F. 1969. Cities and Housing: The Spatial Pattern of Urban Residential Land Use. University of Chicago Press.

Oven, A., and Pekdemir, D. 2006. Office Rent Determinants Utilizing Factor Analysis-A Case Study for Istanbul. Journal of Real Estate Finance and Economics. 33, 51-73.

Plazzi, A., Torous, W., and Valkonov, R. 2008. The Cross-Sectional Dispersion of Commercial Real Estate Returns and Rent Growth: Time Variation and Economic Fluctuations. Real Estate Economics. 36, 403-439.

Sivitanidou, R. 1995. Urban Spatial Variations in Commercial Rents: The Role of Spatial Amenities and Commercial Zoning. Journal of Urban Economics. 38, 23-49.

Sivitanidou, R., and Sivitanides, P. 1999. Office Capitalization Rates: Real Estate and Capital Market Influences. Journal of Real Estate Finance and Economics. 18, 297-322.

Sivitanides, P., Southard, J., Torto, R., and Wheaton, W. 2001. The Determinants of AppraisalBased Capitalization Rates. Real Estate Finance. 18, 27-37.

Wit, I., and Dijk, R. 2003. The Global Determinants of Direct Office Real Estate Returns. Journal of Real Estate Finance and Economics. 26, 27-45. 
Figure 1: Mean Rental Rate of Sample Countries (2000-2017)

Figure 1 plots the mean US dollar denominated rental rate across 29 countries. The rental rate is as defined in Section 3.

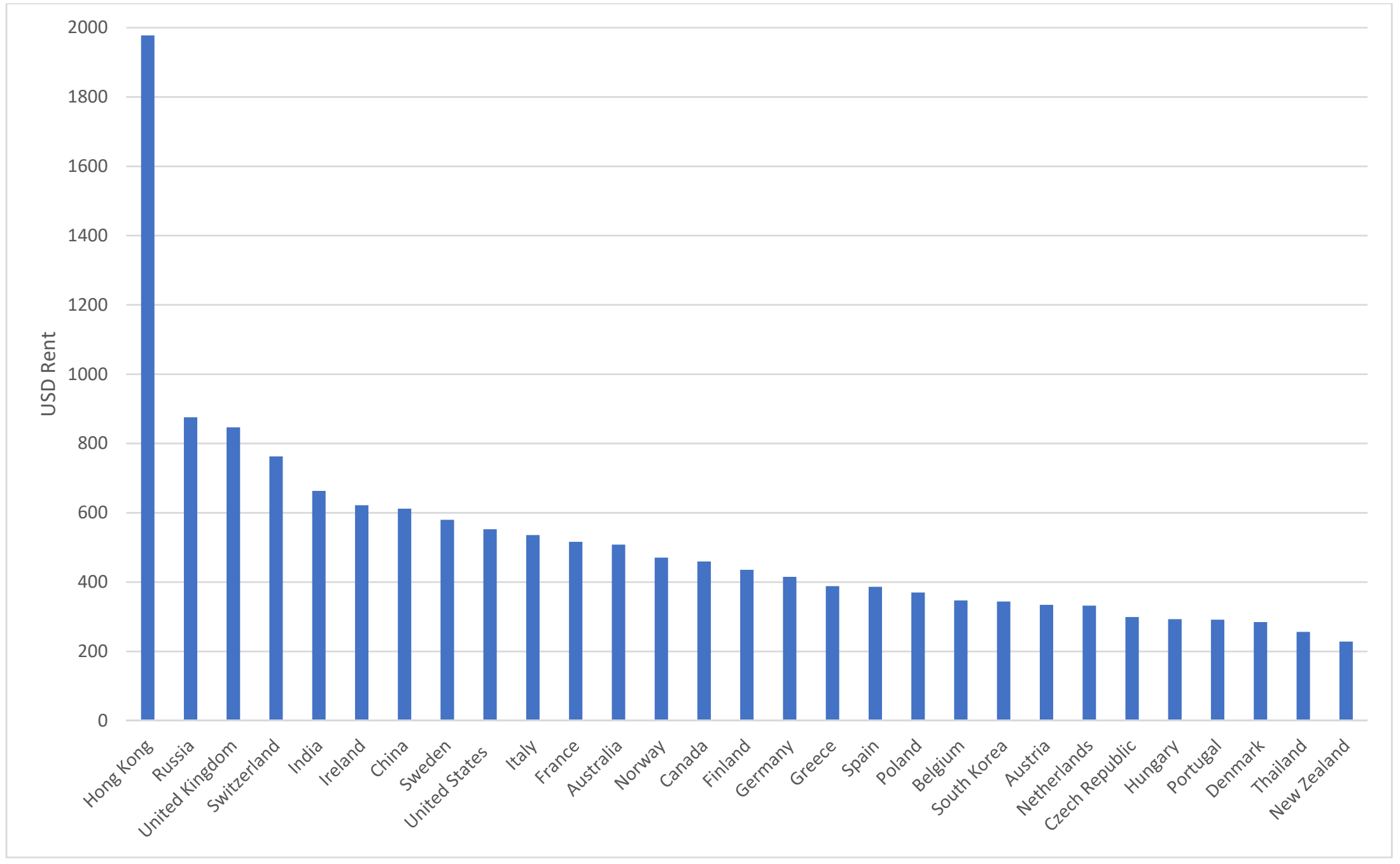


Figure 2: Annual Rental Rate of Sample Countries (2000-2017)

For each year, Figure 2 plots the mean US dollar denominated rental rate across the 29 countries, the 20 European countries and the 11 European countries that adopted the Euro. In addition, for the 11 European countries that adopted the Euro Figure 2 plots the mean Euro denominated rental rate. The rental rate is as defined in Section 3.

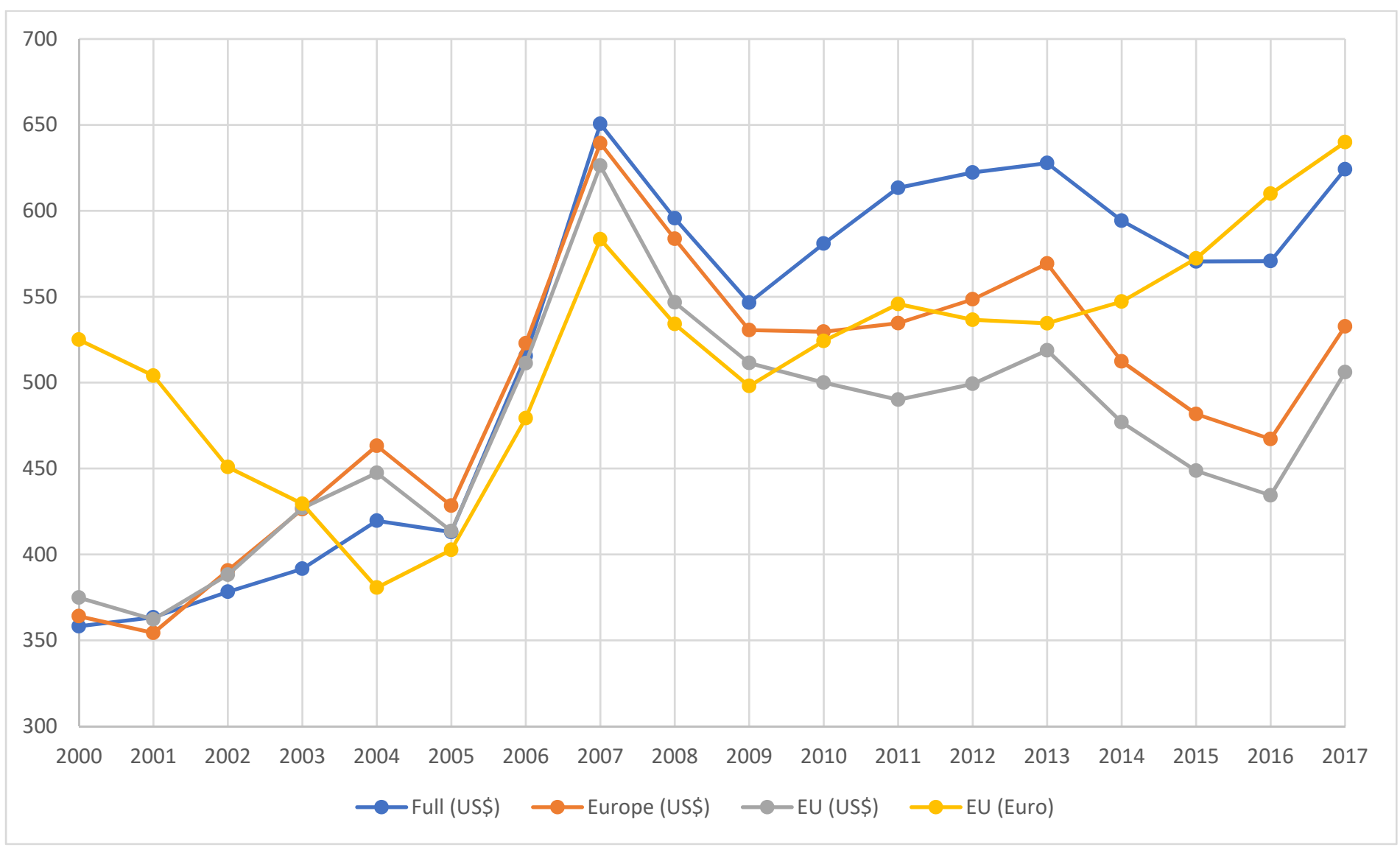


Figure 3: Mean Rental Yields of Sample Countries (2000-2017)

Figure 3 plots the mean rental yield across 29 countries. The rental yield is as defined in Section 3.

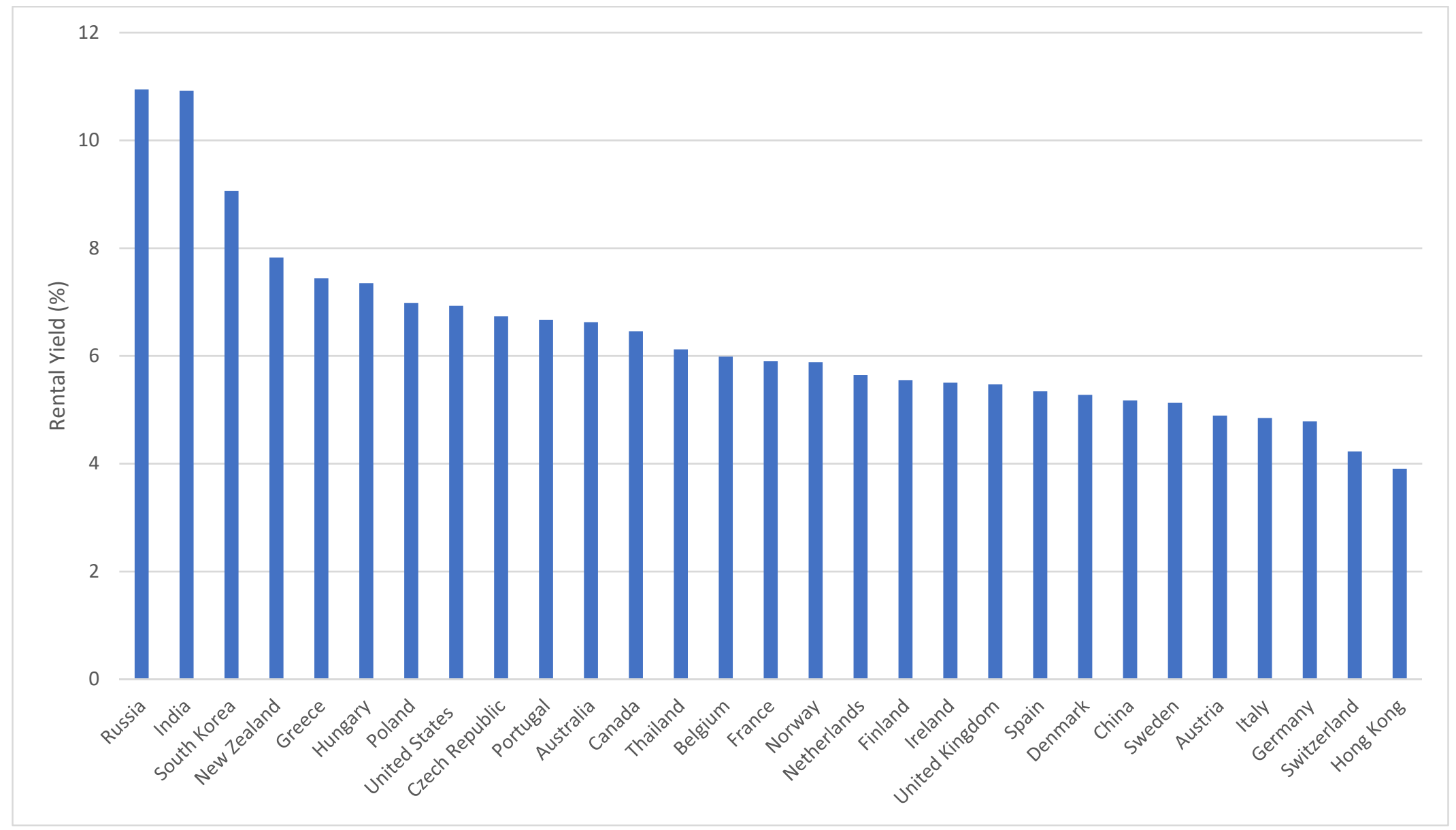




\section{Table 1: Sample}

The table presents sample composition over the period between January 2000 and December 2016.

\begin{tabular}{|c|c|c|c|c|c|c|c|}
\hline \multirow[b]{2}{*}{ Country } & \multicolumn{3}{|c|}{ CBD Rental Rate and Yield } & \multicolumn{2}{|c|}{ Suburban Rent } & \multicolumn{2}{|c|}{ Suburban Yield } \\
\hline & $\begin{array}{c}\text { Number } \\
\text { of cities } \\
\text { per } \\
\text { country }\end{array}$ & $\begin{array}{c}\text { Number of } \\
\text { city/year } \\
\text { observations }\end{array}$ & Europe & $\begin{array}{l}\text { Number } \\
\text { of } \\
\text { suburbs } \\
\text { per } \\
\text { country }\end{array}$ & $\begin{array}{c}\text { Number of } \\
\text { suburb/year } \\
\text { observations }\end{array}$ & $\begin{array}{l}\text { Number } \\
\text { of } \\
\text { suburbs } \\
\text { per } \\
\text { country }\end{array}$ & $\begin{array}{l}\text { Number of } \\
\text { suburb/year } \\
\text { observations }\end{array}$ \\
\hline Australia & 4 & 72 & 0 & 0 & 0 & 0 & 0 \\
\hline Austria & 1 & 18 & 1 & 6 & 66 & 6 & 66 \\
\hline Belgium & 1 & 18 & 1 & 0 & 0 & 0 & 0 \\
\hline Canada & 3 & 54 & 0 & 0 & 0 & 0 & 0 \\
\hline China & 3 & 54 & 0 & 3 & 51 & 0 & 0 \\
\hline Czech Republic & 1 & 18 & 1 & 2 & 24 & 2 & 24 \\
\hline Denmark & 1 & 18 & 1 & 0 & 0 & 0 & 0 \\
\hline Finland & 1 & 18 & 1 & 0 & 0 & 0 & 0 \\
\hline France & 3 & 54 & 1 & 7 & 126 & 7 & 103 \\
\hline Germany & 5 & 90 & 1 & 37 & 495 & 0 & 0 \\
\hline Greece & 1 & 18 & 1 & 3 & 39 & 3 & 39 \\
\hline Hong Kong & 1 & 18 & 0 & 0 & 0 & 0 & 0 \\
\hline Hungary & 1 & 18 & 1 & 0 & 0 & 0 & 0 \\
\hline India & 1 & 18 & 0 & 0 & 0 & 0 & 0 \\
\hline Ireland & 1 & 18 & 1 & 3 & 54 & 3 & 48 \\
\hline Italy & 2 & 36 & 1 & 0 & 0 & 0 & 0 \\
\hline Netherlands & 2 & 36 & 1 & 2 & 32 & 1 & 16 \\
\hline New Zealand & 1 & 18 & 0 & 0 & 0 & 0 & 0 \\
\hline Norway & 1 & 18 & 1 & 0 & 0 & 0 & 0 \\
\hline Poland & 1 & 18 & 1 & 0 & 0 & 0 & 0 \\
\hline Portugal & 1 & 18 & 1 & 0 & 0 & 0 & 0 \\
\hline Russia & 1 & 18 & 1 & 3 & 37 & 3 & 37 \\
\hline South Korea & 1 & 18 & 0 & 2 & 34 & 0 & 0 \\
\hline Spain & 2 & 36 & 1 & 8 & 107 & 8 & 97 \\
\hline Sweden & 1 & 18 & 1 & 0 & 0 & 0 & 0 \\
\hline Switzerland & 2 & 36 & 1 & 3 & 48 & 3 & 48 \\
\hline Thailand & 1 & 18 & 0 & 0 & 0 & 0 & 0 \\
\hline United Kingdom & 3 & 54 & 1 & 0 & 0 & 0 & 0 \\
\hline United States & 5 & 90 & 0 & 7 & 126 & 0 & 0 \\
\hline Total & 52 & 936 & 20 & 86 & 1239 & 36 & 478 \\
\hline
\end{tabular}




\section{Table 2: Summary Statistics}

The table presents summary statistics for our sample. The table provides the mean, standard deviation, median, minimum, and maximum values of each variable. All variables are defined in Sections 3.

\begin{tabular}{|c|c|c|c|c|c|c|}
\hline Variable & $\mathrm{N}$ & Mean & Median & Std Deviation & Minimum & Maximum \\
\hline \multicolumn{7}{|c|}{ CBD - Full Sample } \\
\hline Rent & 936 & 6.1088 & 6.0425 & 0.5197 & 4.3841 & 7.9795 \\
\hline Yield & 912 & 0.0607 & 0.0575 & 0.0179 & 0.0280 & 0.1650 \\
\hline Transport & 936 & 5.4468 & 5.5982 & 0.7569 & 3.0221 & 6.9479 \\
\hline Job density & 936 & 3.0797 & 3.1046 & 0.9040 & 1.2238 & 5.1287 \\
\hline Financial center & 936 & 0.1496 & 0.0000 & 0.3568 & 0.0000 & 1.0000 \\
\hline Capital city & 936 & 0.4423 & 0.0000 & 0.4969 & 0.0000 & 1.0000 \\
\hline Population & 936 & 15.0719 & 14.9043 & 0.8865 & 12.7338 & 17.0323 \\
\hline Population growth & 936 & 0.0099 & 0.0066 & 0.0223 & -0.0774 & 0.2585 \\
\hline GDP per capita & 936 & 9.9198 & 10.1579 & 0.8545 & 6.8167 & 11.3071 \\
\hline Short real rate & 936 & 0.0054 & 0.0037 & 0.0199 & -0.1170 & 0.0999 \\
\hline Inflation & 936 & 0.0224 & 0.0201 & 0.0212 & -0.0447 & 0.2148 \\
\hline Rating & 936 & 0.5557 & 0.0000 & 0.8259 & 0.0000 & 2.8332 \\
\hline \multicolumn{7}{|c|}{ CBD - Europe } \\
\hline Rent & 576 & 6.0821 & 5.9996 & 0.4581 & 5.0465 & 7.8488 \\
\hline Yield & 574 & 0.0570 & 0.0540 & 0.0163 & 0.0300 & 0.1550 \\
\hline Transport & 576 & 5.7424 & 5.7462 & 0.5141 & 4.5433 & 6.9479 \\
\hline Job density & 576 & 3.1827 & 3.2734 & 0.5881 & 1.2238 & 4.9330 \\
\hline Financial center & 576 & 0.1076 & 0.0000 & 0.3102 & 0.0000 & 1.0000 \\
\hline Capital city & 576 & 0.5625 & 1.0000 & 0.4965 & 0.0000 & 1.0000 \\
\hline Population & 576 & 14.7574 & 14.7295 & 0.6615 & 13.4437 & 16.3333 \\
\hline Population growth & 576 & 0.0065 & 0.0067 & 0.0086 & -0.0774 & 0.0719 \\
\hline GDP per capita & 576 & 10.1833 & 10.3156 & 0.5142 & 8.5288 & 11.3071 \\
\hline Short real rate & 576 & 0.0031 & 0.0007 & 0.0201 & -0.1170 & 0.0962 \\
\hline Inflation & 576 & 0.0210 & 0.0174 & 0.0234 & -0.0447 & 0.2148 \\
\hline Rating & 576 & 0.5369 & 0.0000 & 0.8123 & 0.0000 & 2.8332 \\
\hline \multicolumn{7}{|c|}{ Suburb } \\
\hline Suburban rent & 1239 & 5.7042 & 5.6582 & 0.4512 & 4.0144 & 7.3072 \\
\hline CBD-Suburb rent & 1239 & 0.3821 & 0.4174 & 0.2293 & -0.6460 & 0.7625 \\
\hline Suburban yield & 478 & 0.0647 & 0.0605 & 0.0159 & 0.0300 & 0.1200 \\
\hline CBD-Suburb yield & 478 & -0.2217 & -0.1818 & 0.1744 & -0.9333 & 0.1662 \\
\hline Distance & 1239 & 2.2165 & 2.2721 & 0.7450 & 0.3365 & 4.0146 \\
\hline Travel time - public & 1226 & -0.8222 & -0.8755 & 0.6174 & -2.4849 & 0.4274 \\
\hline Travel time - car & 1205 & -0.8157 & -0.7621 & 0.5351 & -2.1484 & 0.6848 \\
\hline
\end{tabular}


Table 3: Correlation Matrix

This table presents a correlation matrix for our sample. Pearson correlation coefficients for all variables, together with each pairing of variables is presented. All variables are defined in Sections 3.

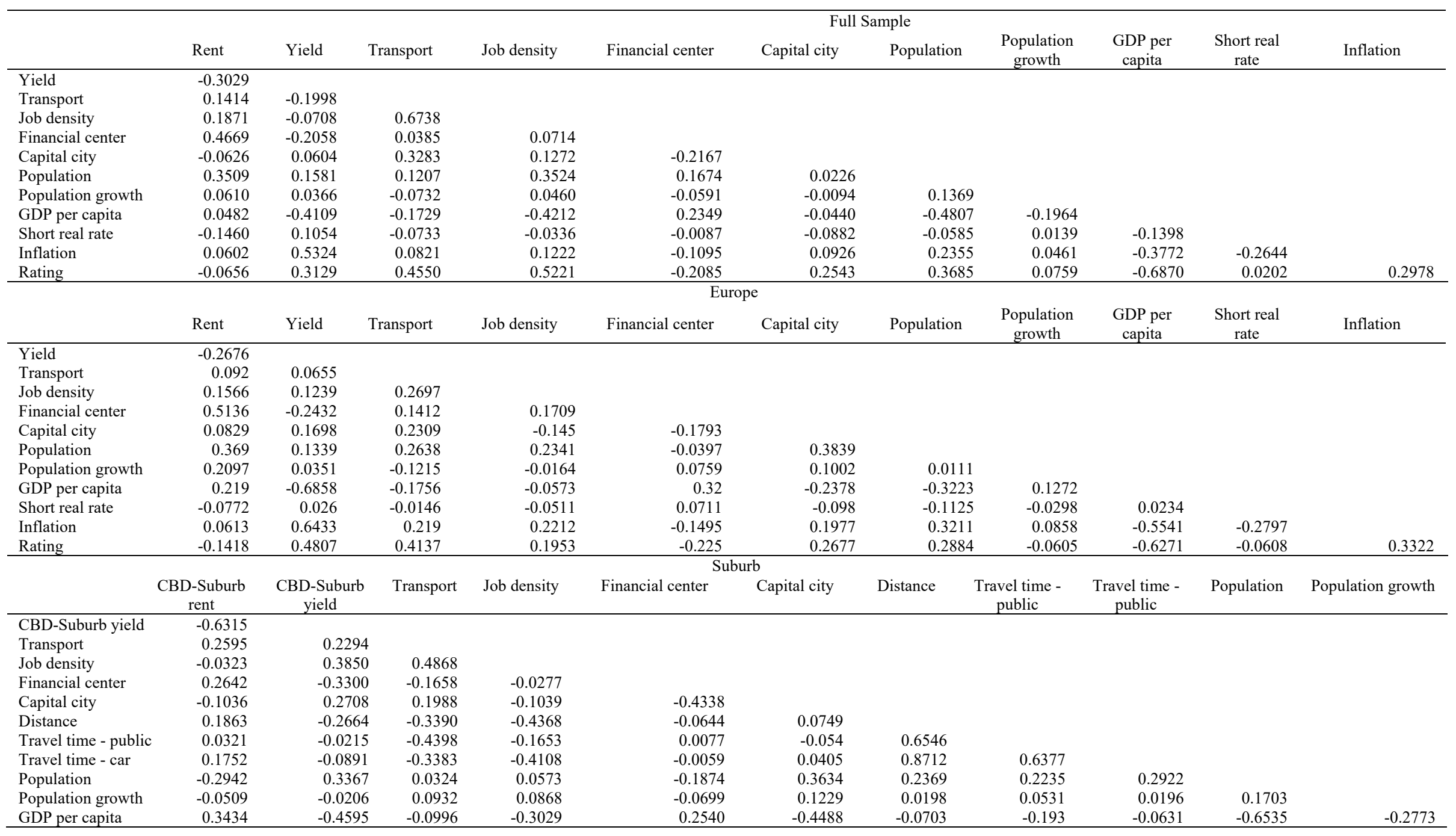




\section{Table 4: CBD Rents - Agglomeration, Transport and Job Density}

This table presents the regression of USD prime rents, Rent, on agglomeration, transport and job density together with city and country level controls as defined in in Section 3. The sample is split into 3 subsamples (2000-2008, 20092017 and European countries). Year fixed effects are included. Standard errors are clustered by city and time. Standard errors are given in parentheses. $* * *, * * *$ denotes $1 \%, 5 \%$ and $10 \%$ significance level.

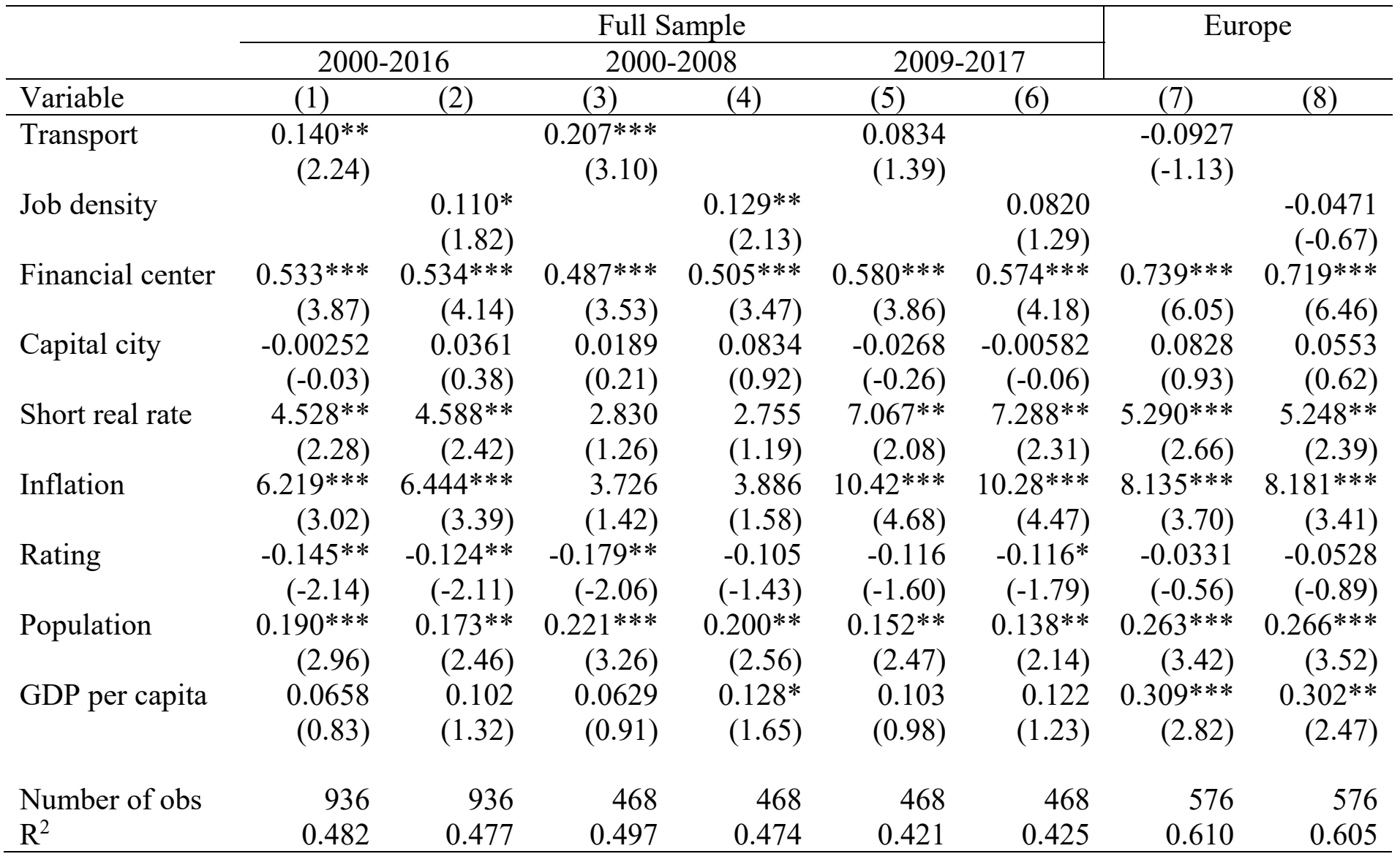




\section{Table 5: CBD Rental Yields - Agglomeration, Transport and Job Density}

This table presents the regression of prime yields, Yield, on agglomeration, transport and job density together with city and country level controls as defined in in Section 3. The sample is split into 3 subsamples (2000-2008, 2009-2017 and European countries). Year fixed effects are included. Standard errors are clustered by city and time. Standard errors are given in parentheses. $* * *, * *, *$ denotes $1 \%, 5 \%$ and $10 \%$ significance level.

\begin{tabular}{|c|c|c|c|c|c|c|c|c|}
\hline \multirow[b]{3}{*}{ Variables } & \multicolumn{6}{|c|}{ Full Sample } & \multirow{2}{*}{\multicolumn{2}{|c|}{ Europe }} \\
\hline & \multicolumn{2}{|c|}{$2000-2016$} & \multicolumn{2}{|c|}{$2000-2008$} & \multicolumn{2}{|c|}{$2009-2017$} & & \\
\hline & (1) & (2) & (3) & (4) & (5) & (6) & (7) & (8) \\
\hline Transport & $\begin{array}{r}-0.00959 * * * \\
(-9.03)\end{array}$ & & $\begin{array}{r}-0.0076 * * * \\
(-5.04)\end{array}$ & & $\begin{array}{r}-0.0108 * * * \\
(-8.82)\end{array}$ & & $\begin{array}{r}-0.0051 * * * \\
(-3.21)\end{array}$ & \\
\hline Job density & & $\begin{array}{r}-0.0055^{* * *} \\
(-3.01)\end{array}$ & & $\begin{array}{r}-0.00197 \\
(-0.88)\end{array}$ & & $\begin{array}{r}-0.0076^{* * *} \\
(-4.72)\end{array}$ & & $\begin{array}{r}0.00120 \\
(1.44)\end{array}$ \\
\hline Financial center & $\begin{array}{r}-0.00304 \\
(-1.40)\end{array}$ & $\begin{array}{r}-0.00390 \\
(-1.45)\end{array}$ & $\begin{array}{r}-0.00335 \\
(-1.04)\end{array}$ & $\begin{array}{r}-0.00500 \\
(-1.25)\end{array}$ & $\begin{array}{r}-0.00195 \\
(-0.89)\end{array}$ & $\begin{array}{r}-0.00237 \\
(-1.07)\end{array}$ & $\begin{array}{r}-0.000813 \\
(-0.39)\end{array}$ & $\begin{array}{r}-0.00316 \\
(-1.17)\end{array}$ \\
\hline Capital city & $\begin{array}{r}0.00196 \\
(0.90)\end{array}$ & $\begin{array}{r}-0.000755 \\
(-0.30)\end{array}$ & $\begin{array}{r}-0.0000378 \\
(-0.01)\end{array}$ & $\begin{array}{r}-0.00269 \\
(-0.91)\end{array}$ & $\begin{array}{r}0.00402 * * \\
(2.01)\end{array}$ & $\begin{array}{r}0.00121 \\
(0.49)\end{array}$ & $\begin{array}{r}0.00143 \\
(0.78)\end{array}$ & $\begin{array}{r}0.00103 \\
(0.55)\end{array}$ \\
\hline Short rate & $\begin{array}{r}0.139 * * * \\
(3.33)\end{array}$ & $\begin{array}{r}0.155^{* * *} \\
(3.19)\end{array}$ & $\begin{array}{r}0.181^{* *} \\
(2.47)\end{array}$ & $\begin{array}{r}0.208 * * \\
(2.41)\end{array}$ & $\begin{array}{r}0.227 * * * \\
(3.32)\end{array}$ & $\begin{array}{r}0.239 * * \\
(2.55)\end{array}$ & $\begin{array}{r}0.138^{* *} \\
(2.18)\end{array}$ & $\begin{array}{r}0.120^{*} \\
(1.76)\end{array}$ \\
\hline Inflation & $\begin{array}{r}0.371 * * * \\
(5.25)\end{array}$ & $\begin{array}{r}0.382 * * * \\
(4.87)\end{array}$ & $\begin{array}{r}0.384 * * * \\
(7.01)\end{array}$ & $\begin{array}{r}0.432 * * * \\
(11.37)\end{array}$ & $\begin{array}{r}0.404 * * * \\
(5.00)\end{array}$ & $\begin{array}{r}0.431 * * * \\
(4.50)\end{array}$ & $\begin{array}{r}0.352 * * * \\
(4.87)\end{array}$ & $\begin{array}{r}0.311^{* * *} \\
(3.55)\end{array}$ \\
\hline Rating & $\begin{array}{r}0.00744 * * * \\
(4.38)\end{array}$ & $\begin{array}{r}0.00493 * * * \\
(2.73)\end{array}$ & $\begin{array}{r}0.00645^{* *} \\
(2.07)\end{array}$ & $\begin{array}{r}0.00148 \\
(0.56)\end{array}$ & $\begin{array}{r}0.00684 * * * \\
(4.98)\end{array}$ & $\begin{array}{r}0.00561 * * * \\
(3.70)\end{array}$ & $\begin{array}{r}0.00485 * * * \\
(3.87)\end{array}$ & $\begin{array}{r}0.00303^{* *} \\
(2.18)\end{array}$ \\
\hline Population & $\begin{array}{r}0.000378 \\
(0.23)\end{array}$ & $\begin{array}{r}0.00121 \\
(0.56)\end{array}$ & $\begin{array}{r}0.00245 \\
(1.07)\end{array}$ & $\begin{array}{r}0.00294 \\
(1.13)\end{array}$ & $\begin{array}{r}-0.00127 \\
(-1.05)\end{array}$ & $\begin{array}{r}-0.0000228 \\
(-0.01)\end{array}$ & $\begin{array}{r}-0.0036^{* * *} \\
(-3.16)\end{array}$ & $\begin{array}{r}-0.0042 * * * \\
(-4.05)\end{array}$ \\
\hline Population growth & $\begin{array}{r}-0.0785 * * * \\
(-2.84)\end{array}$ & $\begin{array}{r}-0.0527^{*} \\
(-1.92)\end{array}$ & $\begin{array}{r}-0.0830 * * * \\
(-2.83)\end{array}$ & $\begin{array}{r}-0.0615^{* *} \\
(-2.46)\end{array}$ & $\begin{array}{r}-0.0644 * * * \\
(-3.14)\end{array}$ & $\begin{array}{r}-0.0296^{*} \\
(-1.81)\end{array}$ & $\begin{array}{r}-0.0378 \\
(-0.71)\end{array}$ & $\begin{array}{r}0.0254 \\
(0.42)\end{array}$ \\
\hline GDP per capita & $\begin{array}{r}-0.00175 \\
(-0.63)\end{array}$ & $\begin{array}{r}-0.00355 \\
(-1.27)\end{array}$ & $\begin{array}{r}-0.00530 \\
(-1.60)\end{array}$ & $\begin{array}{r}-0.00723^{* *} \\
(-2.15)\end{array}$ & $\begin{array}{r}0.000430 \\
(0.16)\end{array}$ & $\begin{array}{r}-0.000987 \\
(-0.39)\end{array}$ & $\begin{array}{r}-0.0099 * * * \\
(-4.89)\end{array}$ & $\begin{array}{r}-0.0118 * * * \\
(-4.79)\end{array}$ \\
\hline Number of obs & 912 & 912 & 444 & 444 & 468 & 468 & 574 & 574 \\
\hline $\mathrm{R}^{2}$ & 0.611 & 0.550 & 0.588 & 0.543 & 0.655 & 0.580 & 0.755 & 0.738 \\
\hline
\end{tabular}




\section{Table 6: CBD versus Suburban Rental Rates}

This table presents the regression of the proportionate change in rental rates between CBD and suburban office space, CBD-Suburb rent, on agglomeration, transport and job density together with travel distances and time, city level controls as defined in in Section 3. Panel A reports results for the full sample of 86 suburbs across 19 mostly European cities, Panel B for the sub sample of 36 suburbs across 10 European cities with suburb-year observations of both rental rates and yields. Year fixed effects are included. Standard errors are clustered by suburb and time. Standard errors are given in parentheses. ${ }^{* * *}, * * *$ denotes $1 \%, 5 \%$ and $10 \%$ significance level.

\begin{tabular}{|c|c|c|c|c|c|c|}
\hline \multicolumn{7}{|c|}{ Panel A } \\
\hline Variable & (1) & (2) & (3) & (4) & (5) & (6) \\
\hline Transport & $\begin{array}{r}0.175 * * * \\
(3.85)\end{array}$ & $\begin{array}{r}0.174 * * * \\
(3.86)\end{array}$ & $\begin{array}{r}0.170 * * * \\
(3.90)\end{array}$ & & & \\
\hline Job density & & & & $\begin{array}{r}0.0910^{* *} \\
(2.47)\end{array}$ & $\begin{array}{r}0.0439 \\
(1.28)\end{array}$ & $\begin{array}{r}0.0930 * * \\
(2.16)\end{array}$ \\
\hline Financial center & $\begin{array}{r}0.201 * * * \\
(4.06)\end{array}$ & $\begin{array}{r}0.191 * * * \\
(3.81)\end{array}$ & $\begin{array}{r}0.205 * * * \\
(4.30)\end{array}$ & $\begin{array}{r}0.184 * * * \\
(3.24)\end{array}$ & $\begin{array}{r}0.169 * * * \\
(2.87)\end{array}$ & $\begin{array}{r}0.196 * * * \\
(3.57)\end{array}$ \\
\hline Capital city & $\begin{array}{r}0.0478 \\
(1.21)\end{array}$ & $\begin{array}{r}0.0838^{* *} \\
(2.07)\end{array}$ & $\begin{array}{r}0.0604 \\
(1.48)\end{array}$ & $\begin{array}{r}0.124^{*} \\
(1.93)\end{array}$ & $\begin{array}{r}0.123 * * \\
(2.01)\end{array}$ & $\begin{array}{r}0.141^{* *} \\
(2.12)\end{array}$ \\
\hline Distance & $\begin{array}{r}0.134 * * * \\
(6.35)\end{array}$ & & & $\begin{array}{r}0.124 * * * \\
(4.79)\end{array}$ & & \\
\hline Travel time - public & & $\begin{array}{r}0.130^{* * *} \\
(4.68)\end{array}$ & & & $\begin{array}{r}0.0669^{* *} \\
(2.13)\end{array}$ & \\
\hline Travel time - car & & & $\begin{array}{r}0.182 * * * \\
(5.85)\end{array}$ & & & $\begin{array}{r}0.163 * * * \\
(4.73)\end{array}$ \\
\hline Population & $\begin{array}{r}-0.0517 * * \\
(-2.51)\end{array}$ & $\begin{array}{r}-0.0336 \\
(-1.60)\end{array}$ & $\begin{array}{r}-0.0576^{* * *} \\
(-2.84)\end{array}$ & $\begin{array}{r}-0.0425^{* *} \\
(-2.28)\end{array}$ & $\begin{array}{r}-0.0270 \\
(-1.46)\end{array}$ & $\begin{array}{r}-0.0429 * * \\
(-2.42)\end{array}$ \\
\hline GDP per capita & $\begin{array}{r}0.0675^{* * *} \\
(2.80)\end{array}$ & $\begin{array}{r}0.104 * * * \\
(4.00)\end{array}$ & $\begin{array}{r}0.0610^{* *} \\
(2.29)\end{array}$ & $\begin{array}{r}0.113 * * * \\
(4.27)\end{array}$ & $\begin{array}{r}0.114 * * * \\
(4.04)\end{array}$ & $\begin{array}{r}0.107^{* * * *} \\
(3.52)\end{array}$ \\
\hline Number of obs & 1239 & 1226 & 1205 & 1239 & 1226 & 1205 \\
\hline $\mathrm{R}^{2}$ & 0.432 & 0.365 & 0.425 & 0.315 & 0.218 & 0.313 \\
\hline
\end{tabular}




\begin{tabular}{|c|c|c|c|c|c|c|}
\hline \multicolumn{7}{|c|}{ Panel B } \\
\hline Variable & (1) & $(2)$ & (3) & (4) & $(5)$ & $(6)$ \\
\hline Transport & $\begin{array}{r}-0.0710 * * \\
(-2.33)\end{array}$ & $\begin{array}{r}-0.0782 * * * \\
(-2.83)\end{array}$ & $\begin{array}{r}-0.0820 * * \\
(-2.28)\end{array}$ & & & \\
\hline Job density & & & & $\begin{array}{r}0.0294 * \\
(1.71)\end{array}$ & $\begin{array}{r}-0.0240 \\
(-1.34)\end{array}$ & $\begin{array}{r}-0.0117 \\
(-0.47)\end{array}$ \\
\hline Financial center & $\begin{array}{r}0.408 * * * \\
(5.13)\end{array}$ & $\begin{array}{r}0.395^{* * *} \\
(3.55)\end{array}$ & $\begin{array}{r}0.352^{* * * *} \\
(3.55)\end{array}$ & $\begin{array}{r}0.320 * * * \\
(4.99)\end{array}$ & $\begin{array}{r}0.325^{* * * *} \\
(3.27)\end{array}$ & $\begin{array}{r}0.264 * * * \\
(2.96)\end{array}$ \\
\hline Capital city & $\begin{array}{r}0.0801 \\
(1.65)\end{array}$ & $\begin{array}{r}0.131 \\
(1.64)\end{array}$ & $\begin{array}{r}0.114 \\
(1.43)\end{array}$ & $\begin{array}{r}0.0677 \\
(1.63)\end{array}$ & $\begin{array}{r}0.104 \\
(1.33)\end{array}$ & $\begin{array}{r}0.0894 \\
(1.12)\end{array}$ \\
\hline Distance & $\begin{array}{r}0.166^{* * * *} \\
(4.66)\end{array}$ & & & $\begin{array}{r}0.197 * * * \\
(5.55)\end{array}$ & & \\
\hline Travel time - public & & $\begin{array}{r}0.0953 * * * \\
(2.66)\end{array}$ & & & $\begin{array}{r}0.108 * * * \\
(2.92)\end{array}$ & \\
\hline Travel time - car & & & $\begin{array}{r}0.104^{*} \\
(1.96)\end{array}$ & & & $\begin{array}{r}0.118^{* *} \\
(2.15)\end{array}$ \\
\hline Population & $\begin{array}{r}0.0352^{* *} * \\
(2.00)\end{array}$ & $\begin{array}{r}0.0326^{*} \\
(1.77)\end{array}$ & $\begin{array}{r}0.0229 \\
(1.16)\end{array}$ & $\begin{array}{r}0.00844 \\
(0.47)\end{array}$ & $\begin{array}{r}0.0123 \\
(0.72)\end{array}$ & $\begin{array}{r}-0.00249 \\
(-0.14)\end{array}$ \\
\hline GDP per capita & $\begin{array}{r}0.0589 * * \\
(2.01)\end{array}$ & $\begin{array}{r}0.0740 * * \\
(2.33)\end{array}$ & $\begin{array}{r}0.0562 * \\
(1.82)\end{array}$ & $\begin{array}{r}0.0754 * * \\
(2.37)\end{array}$ & $\begin{array}{r}0.0677 * * \\
(2.05)\end{array}$ & $\begin{array}{r}0.0534 \\
(1.53)\end{array}$ \\
\hline Number of obs & 478 & 478 & 478 & 478 & 478 & 478 \\
\hline $\mathrm{R}^{2}$ & 0.472 & 0.333 & 0.307 & 0.456 & 0.309 & 0.271 \\
\hline
\end{tabular}




\section{Table 7: CBD versus Suburban Rental Yields}

This table presents the regression of the proportionate change in rental yields between CBD and suburban office space, $C B D$-Suburb yield, on agglomeration, transport and job density together with travel distances and time, city level controls as defined in in Section 3. Year fixed effects are included. Standard errors are clustered by suburb and time. Standard errors are given in parentheses. $* * *, * *, *$ denotes $1 \%, 5 \%$ and $10 \%$ significance level.

\begin{tabular}{|c|c|c|c|c|c|c|}
\hline Variable & $(1)$ & (2) & (3) & (4) & (5) & (6) \\
\hline Transport & $\begin{array}{r}0.0643^{* * *} \\
(2.69)\end{array}$ & $\begin{array}{r}0.0824 * * * \\
(3.17)\end{array}$ & $\begin{array}{r}0.0798 * * \\
(2.51)\end{array}$ & & & \\
\hline Job density & & & & $\begin{array}{r}0.0413 * * \\
(2.20)\end{array}$ & $\begin{array}{r}0.0794 * * * \\
(4.15)\end{array}$ & $\begin{array}{r}0.0726 * * * \\
(2.91)\end{array}$ \\
\hline Financial center & $\begin{array}{r}-0.180 * * \\
(-2.59)\end{array}$ & $\begin{array}{r}-0.152^{*} \\
(-1.66)\end{array}$ & $\begin{array}{l}-0.129 \\
(-1.46)\end{array}$ & $\begin{array}{r}-0.119 * * \\
(-2.12)\end{array}$ & $\begin{array}{l}-0.113 \\
(-1.42)\end{array}$ & $\begin{array}{r}-0.0763 \\
(-0.99)\end{array}$ \\
\hline Capital city & $\begin{array}{r}0.0992 * * \\
(2.42)\end{array}$ & $\begin{array}{r}0.0565 \\
(0.82)\end{array}$ & $\begin{array}{r}0.0665 \\
(0.96)\end{array}$ & $\begin{array}{r}0.127 * * * \\
(2.99)\end{array}$ & $\begin{array}{c}0.104 \\
(1.58)\end{array}$ & $\begin{array}{r}0.113^{*} \\
(1.66)\end{array}$ \\
\hline Distance & $\begin{array}{r}-0.152 * * * \\
(-4.00)\end{array}$ & & & $\begin{array}{r}-0.134 * * * \\
(-3.70)\end{array}$ & & \\
\hline Travel time - public & & $\begin{array}{r}-0.0497 \\
(-1.41)\end{array}$ & & & $\begin{array}{r}-0.0614^{* *} \\
(-2.18)\end{array}$ & \\
\hline Travel time - car & & & $\begin{array}{r}-0.0698 \\
(-1.54)\end{array}$ & & & $\begin{array}{r}-0.0593 \\
(-1.55)\end{array}$ \\
\hline Population & $\begin{array}{r}-0.0107 \\
(-0.77)\end{array}$ & $\begin{array}{r}-0.00814 \\
(-0.56)\end{array}$ & $\begin{array}{r}-0.00144 \\
(-0.10)\end{array}$ & $\begin{array}{r}0.00447 \\
(0.34)\end{array}$ & $\begin{array}{r}0.00281 \\
(0.19)\end{array}$ & $\begin{array}{r}0.0111 \\
(0.79)\end{array}$ \\
\hline Population growth & $\begin{array}{l}-0.539 \\
(-0.91)\end{array}$ & $\begin{array}{l}-0.447 \\
(-0.49)\end{array}$ & $\begin{array}{l}-0.637 \\
(-0.76)\end{array}$ & $\begin{array}{l}-0.519 \\
(-0.76)\end{array}$ & $\begin{array}{r}0.0617 \\
(0.08)\end{array}$ & $\begin{array}{l}-0.304 \\
(-0.45)\end{array}$ \\
\hline GDP per capita & $\begin{array}{r}-0.130 * * * \\
(-5.04)\end{array}$ & $\begin{array}{r}-0.136^{* * *} \\
(-5.40)\end{array}$ & $\begin{array}{r}-0.127 * * * \\
(-5.18)\end{array}$ & $\begin{array}{r}-0.112 * * * \\
(-3.95)\end{array}$ & $\begin{array}{r}-0.104 * * * \\
(-3.76)\end{array}$ & $\begin{array}{r}-0.0954 * * * \\
(-3.24)\end{array}$ \\
\hline Number of obs & 478 & 478 & 478 & 478 & 478 & 478 \\
\hline $\mathrm{R}^{2}$ & 0.570 & 0.430 & 0.434 & 0.573 & 0.500 & 0.485 \\
\hline
\end{tabular}




\section{Table 8: Potential Endogeneity}

This table presents the regression of the CBD USD prime rents, Rent, CBD prime yields, Yield, Proportionate change in rental rates between $\mathrm{CBD}$ and suburban office space, $C B D$-Suburb rent, and Proportionate change in rental yields between $\mathrm{CBD}$ and suburban office space, $C B D$-Suburb yield, on agglomeration together city level controls as defined in in Section 3. Year fixed effects are included. Standard errors are clustered by suburb and time. Standard errors are given in parentheses. ${ }^{* *}, * *, *$ denotes $1 \%, 5 \%$ and $10 \%$ significance level.

\begin{tabular}{|c|c|c|c|c|}
\hline & \multirow{2}{*}{\multicolumn{2}{|c|}{ CBD }} & \multirow{2}{*}{\multicolumn{2}{|c|}{ CBD-Suburb }} \\
\hline & & & & \\
\hline & Rent & Yield & Rent & Yield \\
\hline Variables & (1) & $(2)$ & (3) & (4) \\
\hline \multirow[t]{2}{*}{ Financial center } & $0.567 * * *$ & $-0.00634^{*}$ & $0.163 * * *$ & -0.0119 \\
\hline & (3.56) & $(-1.76)$ & $(2.93)$ & $(-0.15)$ \\
\hline \multirow[t]{2}{*}{ Capital city } & 0.0474 & -0.00123 & 0.0835 & 0.0857 \\
\hline & $(0.48)$ & $(-0.44)$ & $(1.48)$ & $(1.27)$ \\
\hline \multirow[t]{2}{*}{ Short rate } & $3.664 *$ & $0.201 * * *$ & & \\
\hline & $(1.84)$ & $(3.55)$ & & \\
\hline \multirow[t]{2}{*}{ Inflation } & $5.540 * *$ & $0.426 * * *$ & & \\
\hline & (2.49) & $(6.43)$ & & \\
\hline \multirow[t]{2}{*}{ Rating } & -0.0689 & 0.00217 & & \\
\hline & $(-1.08)$ & (1.09) & & \\
\hline \multirow[t]{2}{*}{ Population } & $0.184 * *$ & 0.000648 & -0.0275 & $0.0248 *$ \\
\hline & $(2.52)$ & $(0.28)$ & $(-1.28)$ & (1.94) \\
\hline \multirow[t]{2}{*}{ Population growth } & & -0.0472 & & -1.398 \\
\hline & & $(-1.39)$ & & $(-1.46)$ \\
\hline \multirow[t]{2}{*}{ GDP per capita } & 0.0825 & -0.00248 & $0.0815^{* * *}$ & $-0.127 * * *$ \\
\hline & $(0.98)$ & $(-0.76)$ & $(2.81)$ & $(-5.43)$ \\
\hline Number of obs & 936 & 912 & 1239 & 478 \\
\hline $\mathrm{R}^{2}$ & 0.447 & 0.497 & 0.190 & 0.366 \\
\hline
\end{tabular}

